\title{
Environmental Assessment of Polyaromatic Hydrocarbons in Sediment along Discharge Basin of Suez Oil Refinery Company, Southwest of the Suez Gulf
}

\author{
A. M. Mousa, S. A. Mahmoud* and O. E. Ahmed ${ }^{* \#}$ \\ Chemistry Departments, Faculty of science, Ain Shams \\ University, and ${ }^{*}$ Egyptian Petroleum Research Institute, Nasr \\ City, P.O. 11727, Cairo, Egypt.
}

\begin{abstract}
CCORDING to the IMO declaration, the Gulf area is the most A sensitive and oil-polluted area in the world. Sediment samples were collected from five stations at different distances along discharge basin of Suez Oil petroleum Company (SOPC), in 20122013 and the concentrations of poly-aromatic hydrocarbons were determined by HPLC analysis. The concentrations of $\Sigma$ PAHs were higher than the guideline value $4022 \mathrm{ng} / \mathrm{g}$, due to the aromatic outlet to discharge basin. The concentration of PAHs in the sediments ranged between 22333.983 and $73597.864 \mathrm{ng} / \mathrm{g}$. dry weights with $43016.278 \mathrm{ng} / \mathrm{g}$. dry weights as the average concentration was greater than the guideline; thus, the study area is classified highly polluted. Concentration of the most PAH components were above the ER-L, ER-M, TEL and PEL values in all the sampling stations. The PAHs profiles showed that the $\Sigma 2-3 \& 4$ rings compounds were the major PAHs detected in discharge basin of SOPC. Characteristic ratios of Ant/ (Ant+ Phe), and Flu/ (Flu + Pyr) indicated that PAHs could originate from petrogenic and pyrolytic sources. Petroleum contamination associated with increased industrial processes beside, continuous discharge of the refinery's effluents related by oily smuggling with water to bottom sediments of the discharge basin, without completely treated or degraded easily through weathering processing, which can have side-effects on the ecosystems and human safety, must be controlled.
\end{abstract}

Keywords: PAHs, SOPC, Bottom sediment, Pyrogenic, Petrogenic, Mixed pyrogenic and petrogenic, ERL, PEL, IMO and Guideline value.

Suez Oil petroleum Company (SOPC) industry was considered as one of the most important industry all over the world. It has too many benefits for our life, they have lots of adverse impacts ${ }^{(1)}$. One of the most important industries in the middle of Egypt which has been constructed in the vicinity of the northwest of Suez Gulf (Fig. 1) and its products are:(aromatics, chemicals, fuel) assemble

\#Corresponding author:dr.omaymamosa@yahoo.com 
40\% from local consuming: as solar, (local, banker, electrical station), benzene (80, 90, 92), botogas, mazote by different types and characterization, sulfur (liquid and solid types) asphalt $(60,70)$ as a principal production and propane, asphalt, distilled wax as a secondary production.

Discharge basin of petroleum Suez Company is a semi- enclosed aquatic ecosystem with semidiurnal tide and the tidal current has caused (Fig. 2), Suez Gulf to be wholly affected by the discharged pollutants ${ }^{(2,3)}$. According to the IMO (International Maritime organization) declaration, the Gulf area is the most sensitive area in the world and DOE (Department of Environment) has reported, Gulf is the most oil-polluted marine area in the world ${ }^{(4-7)}$. Many studies showed that the lipophilic characteristics of poly-aromatic hydrocarbons, their tendency to accumulate in sediments, their low degradation rate and high stability, also their potential to manifest the eco-toxicological activity, the concentration of PAH in sediment is an appropriate index of the status of contaminates in marine environment ${ }^{(8-11)}$ and due to these characteristics, it can adsorb to the suspended particulate matter and accumulate in bottom sediments and it can remain unchanged and toxic for long term; therefore, they can have a long term effect on the structure of the benthic community ${ }^{(12)}$. There upon, according to the sensitivity of Gulf area, several studies have been performed on various pollutants. In 1996, studies showed that the Iranian coastal area (especially the southern region along the Imam Khomeini port) was contaminated with petroleum hydrocarbons and this area was classified as slightly polluted ${ }^{(12)}$. In 2004, the Research Institute of the Petroleum Industry showed that the most polluted areas in Musa Bay were located in the vicinity of petrochemical industries and Mahshahr oil export terminal and it showed that Musa bay is more polluted than other Arabic coastal areas, some authors ${ }^{(13-15)}$ provided important data set on PAH levels in sediments along harbor line, Mumbai, India. Refining of oil is the company's main activity to produce petroleumderivative products like naphtha, kerosene, gasoline, asphalt, at Al -Nasr OIL Company. The company is one of the companies owned by the Egyptian Public Petroleum Corporation and lies in the most northerly tip of the Gulf of Suez south east of El-zait Harbor, the company discharges oily wastewater of $144,000 \mathrm{~m} 3 /$ day into the Gulf of Suez ${ }^{(16)}$. The levels of PAHs in sediment were several folds higher than the other study reports from various countries. The PAH distribution profile indicated potential source dependence, as the levels were generally higher in the vicinity of known inputs such as oil terminals and ports. There are implications for the quality of seafood from many aquaculture areas destined for human consumption. The findings point to the urgent need to establish a monitoring programmed for persistent organic pollutants such as PAHs, not only in sediment but also in the organisms themselves to ensure that any excess in concentrations over environmental quality standards is rapidly reported and necessary actions are taken. Their presence in Gulf sediments combined with other potentially toxic compounds can result in negative effects, which have yet to be investigated to any great extent.

Egypt. J. Chem. 57, No. 3 (2014) 


\section{Materials and Methods}

The reagents were all analytical reagent grade or chemically pure. All solvents were redistilled and dried before use by standard procedures ${ }^{(17)}$. All the oils-extracted from surface sediment samples were analyzed according to the standard test method IP318/75 ${ }^{(17)}$. The apparatus used was water HPLC 600, Auto Sampler 616 Plus, Dual Absorbance Detector 2487, attached to a computerized system with Millennium 32 Software $^{(18)}$.

\section{Area of study on the Suez Gulf}

Suez Gulf to be wholly affected by the discharged pollutants (Fig. 1 \& 2). Outlet wastewaters of Suez Oil Petroleum Company are located in area about 2-3 km south west of Suez city and closed to the most important and famous international way. The minimum areas and dimensions for discharge basin as a final design: Number of channel (n) is 2, the maximum width, (B) $=55 \mathrm{~m}$. Depth, $(\mathrm{d})=3.5 \mathrm{~m}$. Length, $(\mathrm{L})=148 \mathrm{~m}$. Sampling station has been selected to appreciate the direct influence of associated oil activities. Suez Gulf relative to a reference background level represented by the discharge basin of (SOPC) ${ }^{(16)}$.

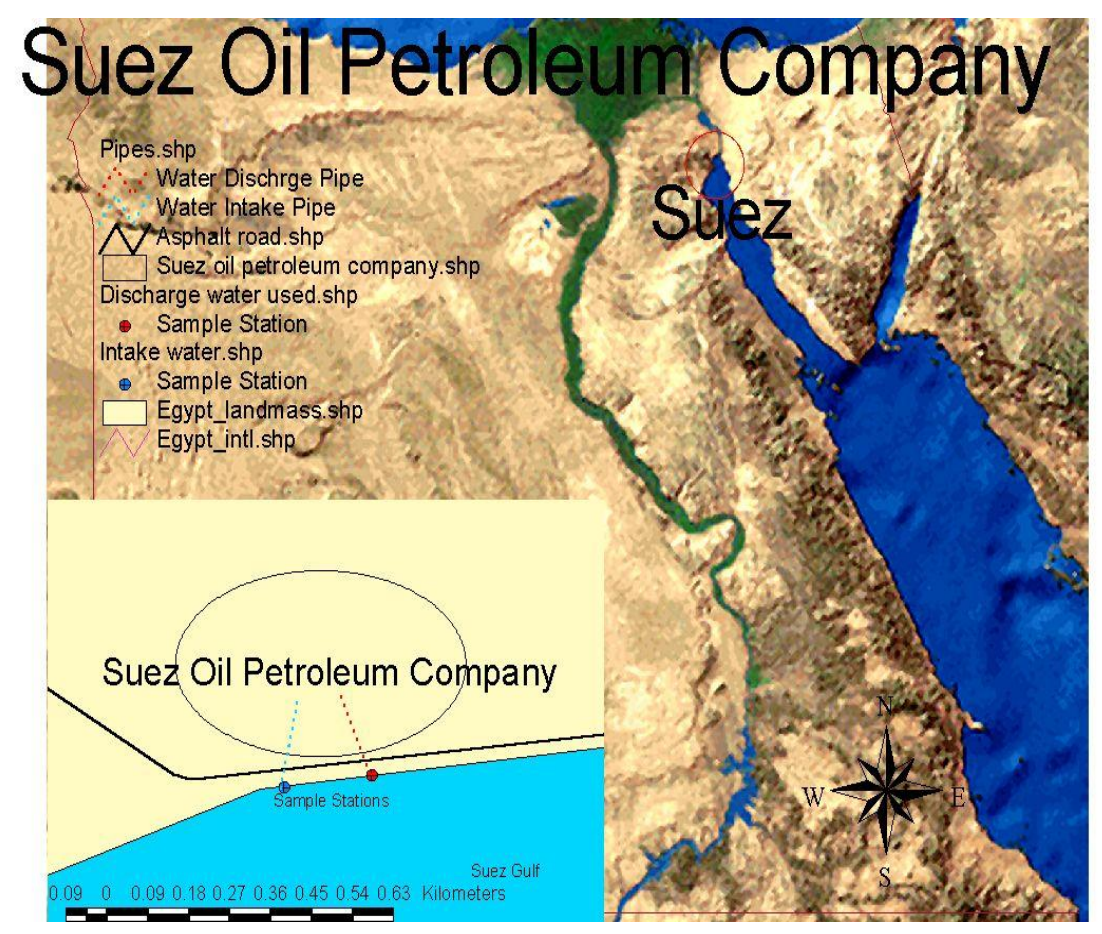

Fig.1. Position of (SOPC) along the Suez Gulf . 


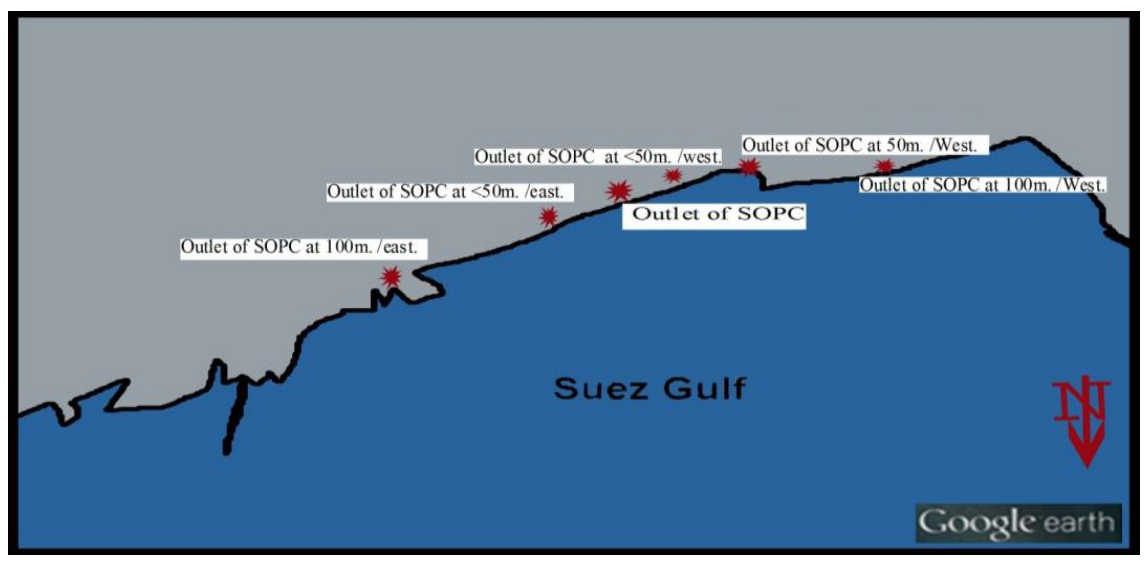

Fig.2. Map of sample stations along the drainage basin of SOPC .

\section{Samples collection and storage}

Surface sediment $(0-2 \mathrm{~cm})$ samples were collected using a stainless stell grab, from different stations along discharge basin of the company, according to activities for each site and distance (Table 1), then mixed and stored in refrigerator in pre - cleaned jars until analysis ${ }^{(19)}$.

TABLE 1. Studied sites, their locations, activities and distance along the drainage Basin of (SOPC) .

\begin{tabular}{|c|c|c|c|}
\hline S. No. & Locations & Activities for each site & $\begin{array}{c}\text { Distance along } \\
\text { drainage basin (m.) }\end{array}$ \\
\hline 7 & $\begin{array}{l}\text { Outlet of Suez Oil } \\
\text { Petroleum Company } \\
\text { at } 100 \mathrm{~m} \text {. /west. }\end{array}$ & $\begin{array}{l}\text { Wastes of conversion operations of crude } \\
\text { oil to refined products along the west } \\
\text { side of the outlet of petroleum drainage } \\
\text { of Suez Company with } 100 \mathrm{~m}\end{array}$ & 100m. /west. \\
\hline 9 & $\begin{array}{l}\text { Outlet of Suez Oil } \\
\text { Petroleum Company } \\
\text { at } 50 \mathrm{~m} \text {. /west. }\end{array}$ & $\begin{array}{l}\text { Wastes of conversion operations of } \\
\text { crude oil to refined products along the } \\
\text { west side of the outlet of petroleum } \\
\text { drainage of Suez Company with } 50 \mathrm{~m}\end{array}$ & $50 \mathrm{~m}$. / west. \\
\hline 8 & $\begin{array}{l}\text { Outlet of Suez Oil } \\
\text { Petroleum Company } \\
\text { at }<50 \mathrm{~m} \text {. /west. }\end{array}$ & $\begin{array}{l}\text { Wastes of conversion operations of } \\
\text { crude oil to refined products along the } \\
\text { west side of the outlet of petroleum } \\
\text { drainage of Suez Company with } 50 \mathrm{~m}\end{array}$ & $<50 \mathrm{~m}$. /west. \\
\hline 10 & $\begin{array}{l}\text { Outlet of Suez Oil } \\
\text { Petroleum Company } \\
\text { at }<50 \mathrm{~m} \text {. /east. }\end{array}$ & $\begin{array}{l}\text { Wastes of conversion operations of } \\
\text { crude oil to refined products along the } \\
\text { east side of the outlet of petroleum } \\
\text { drainage of Suez Company with } 50 \mathrm{~m}\end{array}$ & $<50 \mathrm{~m}$. /east. \\
\hline $10 *$ & $\begin{array}{l}\text { Outlet of Suez Oil } \\
\text { Petroleum Company } \\
\text { at } 100 \mathrm{~m} \text {. /east. }\end{array}$ & $\begin{array}{l}\text { Wastes of conversion operations of crude } \\
\text { oil to refined products along the east } \\
\text { side of the outlet of petroleum drainage } \\
\text { of Suez Company with } 100 \mathrm{~m}\end{array}$ & $100 \mathrm{~m}$. /east. \\
\hline
\end{tabular}

M: Meter's

Egypt. J. Chem. 57, No. 3 (2014) 


\section{Extraction of petroleum oil from sediment samples}

$500 \mathrm{~g}$. of dried, sediment were added in round bottom flask with $300 \mathrm{ml}$, methanol and $15 \mathrm{~g}$. potassium hydroxide. The mixture were refluxed for $1 \mathrm{hr}$ and $30 \mathrm{~min}$ then cooled to room temperature. The methanol extracted twice with $25 \mathrm{ml} n$-hexane, then, the extract was filtered through anhydrous sodium sulphate. The volume was reduced to $0.5 \mathrm{ml}$. The reduced volume was transferred quantitively to glass vial. The extracted oil was concentrated to approximately $0.2 \mathrm{ml}$ using dry nitrogen. The oil content in sediment was then calculated after removing the solvent till constant wt. ${ }^{(20)}$.

\section{High performance liquid chromatography Analysis (HPLC)}

PAH identification and quantification in the extracted oil were performed using HPLC technique ${ }^{(18)}$. The apparatus used was water HPLC 600, Auto Sampler 616 Plus, Dual Absorbance Detector 2487, attached to a computerized system with Millennium 32 Software. The following were the HPLC conditions: the sample volume was $100 \mu \mathrm{L}$; the column used was Supelcosil LC-PAHs $15 \mathrm{~cm}, 4.6 \mathrm{~mm}$ ID, 4- $\mu \mathrm{m}$ particles; mobile phase was achieved using a acetonitrile/water ratio of $60: 40$ and was changed gradually to $100 \%$ acetonitrile within $20 \mathrm{~min}$. The flow rate was $1.2 \mathrm{ml} / \mathrm{min}$, and the detector used was a UV type, $254 \mathrm{~mm}$.

\section{Results and Discussion}

Concentration of total TPAHs in polluted sediments along the drainage basin of SOPC

The concentrations of PAHs and TPAHs in the sediment of different stations are shown in Table 2 and Fig. 3. The PAHs components were distributed in various stations with different patterns. This difference in PAHs composition might be related to the extent and the nature of inputs along the discharge basin. At all of the stations, the concentration of $\Sigma$ PAHs was higher compared to the guideline value $(4022 \mathrm{ng} / \mathrm{g})^{(21,22)}$. The PAHs concentration varied significantly among the SOPC within the discharge basin from 22333.983 up to $73597.864 \mathrm{ng} / \mathrm{g}$ dry weights with $43016.278 \mathrm{ng} / \mathrm{g}$ dry weights as an average concentration was greater than the guideline, high value represented at site (3)73597.864 $\mathrm{ng} / \mathrm{g}$ dry weights while, low value at site $\left(10^{*}\right)$ $22333.983 \mathrm{ng} / \mathrm{g}$ dry weights. This is consistent with the direction of the water currents and winds from the west to the east side's within the discharge basin. On the other hand, a steady decline of the level of poly-aromatic hydrocarbons towards the east, then followed by a rise in poly-aromatic concentration at $<50 \mathrm{~m}$. /east of outlet of SOPC site recorded $39180.36 \mathrm{ng} / \mathrm{g}$ dry weights, this is attributed to the presence of this side from nearby petroleum Nasr Company (outlet), which is closed to Suez Oil Company. Generally, the level of polyaromatic hydrocarbons in the sediments at all study areas is found to vary widely depending on sites with the west coast of discharge basin recorded 
higher values than the east coast ones, this is consistent with the direction of the water currents and winds from the west to the east side's within the basin. The Suez Oil Company takes water from the Suez bay and mixes it with fresh water to utilize in washing the crude oil, after the use of water for this purposes different some oily smuggling occurs for water. Source of salt water necessary for cooling various company in Suez Gulf is characterized by oily water that contains a high proportion of the oil which is caused by refinery production units (Coking - distillation - oils), liquidation warehouses crude and petroleum products, water waste companies neighboring filter wards pumps, Trenchant grids crude and petroleum products. Are assembled this oily water and pushed through a network of lines to basins separated oil. These high values may point out that high residual petroleum fractions are precipitated on sediments. These residual petroleum fractions of oil cannot be completely treated (untreated) or degraded easily through weathering processing, consequently, this leads to accumulation of oil residues in sediments. The drainage basin was under stress from intensive wastes of conversion operations of crude oil to refined products along the east and west sides from it. The deliberate drainage of oil related activities and oily smuggling from the industrial processing cause's continuous inputs and large cumulative loading on the discharge basin water and shore sediments. Also mean, minimum and maximum concentration of PAH components in this area compared to the guidelines $(23,24)$. Concentrations were more than the guideline value in most of the stations (Table 3) and it indicates that occasionally adverse biological effects are likely to accrue for these components in these area average concentrations of $\Sigma$ PAHs $(\mathrm{ng} / \mathrm{g})$ in sampling stations.

TABLE 2. Average concentration of $\Sigma$ PAHs (ng/g dry weight) in the oil extracted from drainage basin of SOPC.

\begin{tabular}{|c|c|c|}
\hline S.NO. & Location & $\begin{array}{c}\text { Conc. } \mathbf{\Sigma} \text { PAHs } \\
(\mathbf{n g} / \mathbf{g})\end{array}$ \\
\hline $\mathbf{7}$ & Outlet of Suez Oil Petroleum Company at 100m. /West. & 73597.864 \\
\hline $\mathbf{9}$ & Outlet of Suez Oil Petroleum Company at 50m. /West. & 47384.966 \\
\hline $\mathbf{8}$ & Outlet of Suez Oil Petroleum Company at <50m. /west. & 32584.224 \\
\hline $\mathbf{1 0}$ & Outlet of Suez Oil Petroleum Company at <50m. /east. & 39180.36 \\
\hline $\mathbf{1 0 *}$ & Outlet of Suez Oil Petroleum Company at $100 \mathrm{~m} . /$ /east. & 22333.983 \\
\hline
\end{tabular}

Conc.: Concentration (ng/g), m.: meter.

Egypt. J. Chem. 57, No. 3 (2014) 


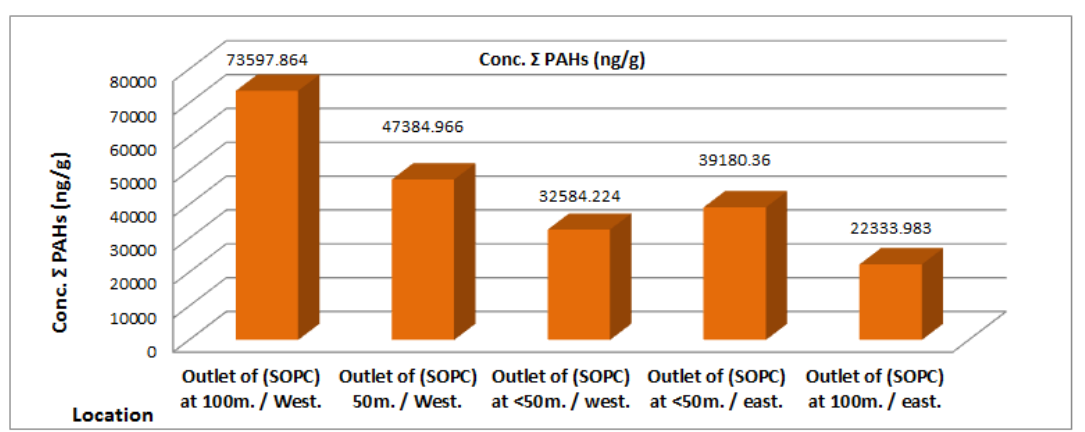

Fig. 3. Average concentration of $\Sigma$ PAHs (ng/g) in the oil extracted from drainage basin of SOPC.

TABLE 3. Mean minimum and maximum concentration of PAHs (ng/g dry weight) in the oil extracted from drainage basin compared to the guideline.

\begin{tabular}{|c|c|c|c|c|}
\hline S.NO. & $\begin{array}{c}\text { T0tal } \\
\boldsymbol{\Sigma} \text { PAHs }\end{array}$ & Minimum & Maximum & Guideline $^{\mathbf{1}}$ \\
\hline $\mathbf{7}$ & 73597.864 & 11.141 & 9628.942 & 4022 \\
\hline $\mathbf{9}$ & 47384.966 & 0.2144 & 16972.595 & 4022 \\
\hline $\mathbf{8}$ & 32584.224 & 9.416 & 10578.204 & 4022 \\
\hline $\mathbf{1 0}$ & 39180.36 & 6.746 & 15175.524 & 4022 \\
\hline $\mathbf{1 0} *$ & 22333.983 & 2.0311 & 10287.232 & 4022 \\
\hline $\begin{array}{c}\text { Mean } \\
\mathbf{~ P A H s}\end{array}$ & $\mathbf{4 3 0 1 6 . 2 7 8}$ & $\mathbf{0 . 2 1 4 4}$ & $\mathbf{1 6 9 7 2 . 5 9 5}$ & $\mathbf{4 0 2 2}$ \\
\hline
\end{tabular}

Comparison of literature data about total TPAH concentrations in sediments from various marine sites in the world

Aromatic hydrocarbons were analyzed to reveal the presence of PAHs contamination relative to pyrolytic or petrogenic origins in sediments of discharge basin. Results show that 16 PAHs can be identified at detectable levels, the total amount of PAHs examined ranged from 22333.983 up to 73597. $864 \mathrm{ng} / \mathrm{g}$ dry weights with $43016.278 \mathrm{ng} / \mathrm{g}$ dry weight, as the average concentration (Table 3) . An understanding of the local and global extent and severity of marine environment contamination by fossil fuel hydrocarbons from various sources requires measuring the compounds of interest and comparing them in different regions. The total PAHs concentration measured in the discharge basin indicates that the sediment contamination is important, and comparable to that found in other locations around the world. TPAHs concentration in sediment from various sites in the world, the investigation of the study area in general could be considered as highly contaminated by PAHs. In 2004, the Research Institute of the Petroleum Industry showed that the most polluted areas in Musa Bay were located in the vicinity of petrochemical industries ${ }^{(13)}$ and reverse concentration ranged between 537.9 to $2713.33 \mathrm{ng} / \mathrm{g}^{(14)}$. In 2009 , concentration of PAHs in the sediments of Imam Khomeini Port were monitored 
and the concentration of PAH concentration was $(190-3520 \mathrm{ng} / \mathrm{g})^{(25)}$. In 1996 , the concentration limits of $\Sigma$ PAHs for marine sediments was considered $(4022 n g / g)^{(22)}$ and Canadian Environmental Quality Guidelines present this value $\left(7071 \mathrm{ng} / \mathrm{g}\right.$ ), in $2002^{(22)}$, National comparison revealed, elevated PAH concentrations in the Santander Bay, Spanish $20-34,460 \mathrm{ng} / \mathrm{g}^{(20)}$, in the Gulf of Trieste, Northern Adriatica $297-115,854 \mathrm{ng} / \mathrm{g}^{(26)}$, and in the western Xiamin Sea 2,900-61,000 ng/g (27), and comparable to that found in other locations around the world (Table 4), the comparison showed higher sedimentary concentrations of PAHs in discharge basin compared with those found in the sediment of Persian Gulf, Iran, Busheher 884-4792 ng/g (21) 34.67 - 682.29 \& 600-800 ng/g in the year $2010 \& 2001$, respectively ${ }^{(28,29)}$, in Alexandria Sea Coasts, Egypt 558.258-2924.273. Mumbai in India $2608-13413 \mathrm{ng} / \mathrm{g}{ }^{(15)}$, Western Xiamen Bay in China 247-480 ng/g ${ }^{(30)}$, Western Baltic Sea 3-30,100ng/g (31), San Francisco Bay in USA 2,653-27,680 ng/g ${ }^{(32)}$, Yangtze Estuary in China 107$633 \mathrm{ng} / \mathrm{g}^{(33)}$, and higher than those found in Kaohsiung Harbor in Taiwan 472$16,207 \mathrm{ng} / \mathrm{g}^{(34)}$. The drainage basin was under stress from intensive wastes of conversion operations of crude oil to refined products along the east and west sides from it. The deliberate drainage of oil related activities and oily smuggling from the industrial processing cause's continuous inputs and large cumulative loading on the discharge basin water and bottom sediments, which may explain the observable difference between the concentrations in the sediments. In fact this region is subject to hydrocarbon pollution by industrial processing waste, and other non-point source pollution .

TABLE 4. Comparison of literature data about total PAH concentrations (nglg dry weight) in sediments by various marine sites in the world .

\begin{tabular}{|l|l|l|l|l|l|}
\hline Location & $\mathbf{N}^{\mathbf{a}}$ & $\begin{array}{l}\mathbf{N}^{\mathbf{b}} \\
\text { PAHs }\end{array}$ & $\begin{array}{l}\text { Concentration } \\
\text { range nglg }\end{array}$ & Method & Preferences \\
\hline $\begin{array}{l}\text { Drainage basin of SOPC } \\
\text { Suez Gulf, Egypt }\end{array}$ & 5 & -- & $22333.983-73597.864$ & HPLC & This work \\
\hline $\begin{array}{l}\text { Gulf of Trieste, Northern } \\
\text { Adriatic a }\end{array}$ & 10 & 24 & $297-115,854$ & GC-FID & $(26)$ \\
\hline Xiamen Harbor, China & 9 & 8 & $2,900-61,000$ & GC-FID & $(27)$ \\
\hline $\begin{array}{l}\text { Santander Bay, Spanish } \\
\text { Gulf of Trieste Northern } \\
\text { Adriatic }\end{array}$ & - & - & $20-34,460$ & $\begin{array}{l}\text { HPLC, } \\
\text { GC/MS }\end{array}$ & $(20)$ \\
\hline $\begin{array}{l}\text { Gulf of Trieste, Northern } \\
\text { Adriatic }\end{array}$ & 3 & 22 & $34.67-682.29$ & GC-MS & $(28)$ \\
\hline Western Xiamen Bay, China & 8 & 16 & $247-480$ & GC-MS & $(29)$ \\
\hline Western Baltic Sea & 22 & 14 & $3-30,100$ & GC-FID & $(30)$ \\
\hline San Francisco Bay, USA & 16 & 17 & $2,653-27,680$ & GC-MS & $(31)$ \\
\hline Yangtze Estuary, China & - & - & $107-633$ & GC-MS & $(32)$ \\
\hline Kaohsiung Harbor, Taiwan & 17 & 16 & $472-16,207$ & HPLC & $(33)$ \\
\hline Mumbai, India & 27 & 15 & $2608-13413$ & HPLC & $(34)$ \\
\hline Persian Gulf, Iran, Busheher & 5 & 16 & $884-4792$ & HPLC & $(15)$ \\
\hline $\begin{array}{l}\text { Alexandria Sea Coasts, } \\
\text { Egypt }\end{array}$ & - & 16 & $558.258-2924.273$ & HPLC & $(21)$ \\
\hline
\end{tabular}

$\mathrm{N}^{\mathrm{a}}$ : the number of samples, Nb PAHs: the number of PAH compounds analyzed in each study .

Egypt. J. Chem. 57, No. 3 (2014) 


\section{Comparing the guidelines of individual poly-aromatic hydrocarbons contaminated sediments}

16-US EPA PAHs (Fig. 4) was grouped in four groups according to their number of aromatic rings. The concentration of TPAHs representing 2-3 ring, 4ring, 5-ring and 6-ring PAHs are shown in Table 5. 2-3 Rings and 4-rings, beside 6-ring, the most abundant PAH compounds in sediment were, acenaphthylene (A), acenaphthene (Ace), phenanthrene (Phe), flourene (F), naphthalene (Nap), anthracene (Ant), fluorantkane (Flu), pyrene (Pyr), benzo [a] anthracene (BaA), chrysene (Chr), benzo [ghi] perlyene (Bp) and indo[1,2,3-cd] pyrene (IP) shown (Fig. 5\&6). The high PAHs level was observed at all the stations along the discharge basin and it may be due to the locations of the sampling point of the aromatic in outlet of Basin Company, with the continuous accumulation of effluents pollutants beside, the depth of this station was low. In this research minimum and maximum concentration of PAH components in the area compared to the guidelines ${ }^{(23,24)}$ and two sets of SQGs including the ERL/ERM and TEL/PEL values, were used as a guideline (Tables $6 \& 7$ ). Concentrations of the most PAH components were higher than the ER-L, ER-M, TEL and PEL values in all the sampling stations, and also higher than national sediment quality criteria purposed by USEA ${ }^{(35)}$ for fluoranthne (Flu) $3000 \mathrm{ng} / \mathrm{g}$ dry wt., phenanthrene (Phe) 2400 ng/g dry wt., acenaphthylene (A) 2400 ng/g dry wt., which might need a more detailed study, the results of this study reverse that banzo (A) anthracene $[\mathrm{BaA}]$ concentrations were low than the TEL /PEL and ER-L/ ER-M, in all the stations, in addition chrysene (Chr) was higher than ER-L/TEL values and lower than ER-L/PEL values also dibenzo [a,h] anthracene (DahA) have lower values than ER-L/ ER-M, \& PEL and higher value TEL. In fact, the presence of fluoranthene (Flu) and pyrene (Pyr) indicates the importance of pyrolytic inputs since, these compounds are considered as products formed from the condensation of aromatic compounds of low molecular weight at high temperature ${ }^{(36)}$. Chrysene is the most important representative toxic $\mathrm{PAH}$, in the discharge basin of SOPC. Chrysene is considered as a preserved biomarker of PAHs and it was selected to be a good marker of petroleum compounds because of its resistance to a biotic factors and bacterial degradation (3). Chrysene showed highly concentration in sediment of drainage basin, reflecting a petrogenic contamination. High concentrations of chrysene can be associated with weathering effect in crude oil and chemical composition change. In addition, high concentration of chrysene considered as conservative PAH due to its resistance to weathering and bacterial degradation, indicates petroleum contamination input in the discharge basin. Higher concentrations of perylene could however, result from terrigenous precursors whose diagenetic degradation could lead to the formation of perylene and indicates biogenic contribution ${ }^{(36)}$. Similarly, that chronic exposure to sediments contaminated with PAHs known for their carcinogenic, mutagenic and teratogenic properties are benz [a] anthracene and chrysene, benzo [b] fluoranthene, benzo [k] fluoranthene, benzo [a] pyrene, benzo [ghi] perylene, dibenz (a,h) anthracene (C20H14), and indeno (1,2,3-cd) pyrene (C22H12) ${ }^{(37)}$. 


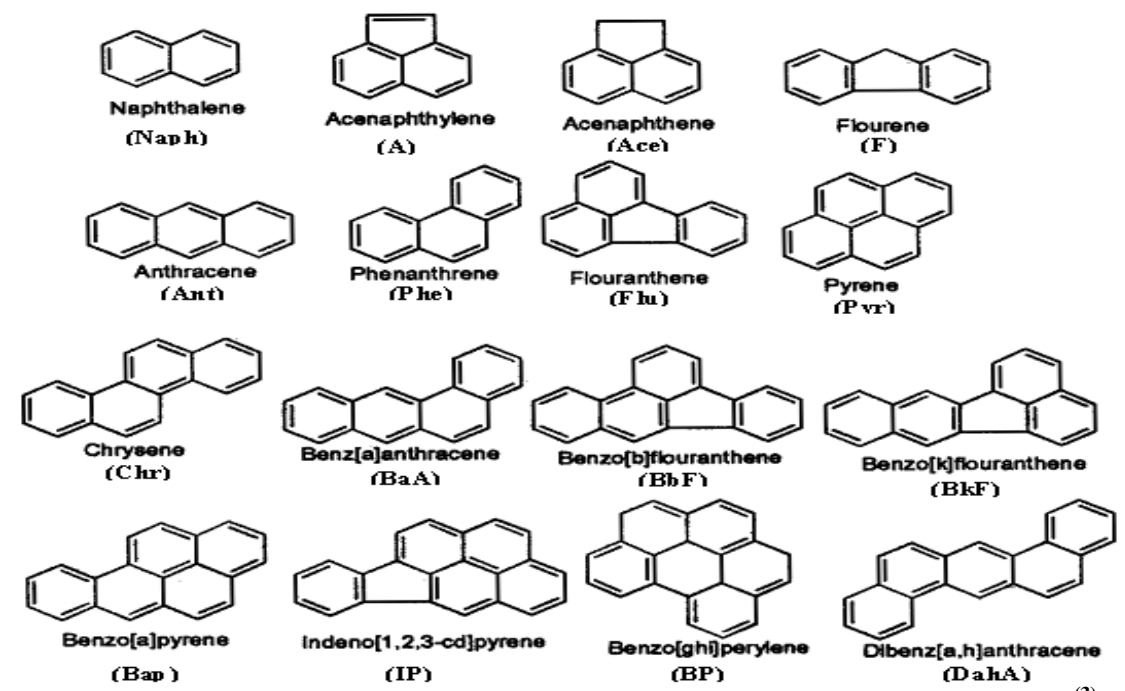

Fig. 4. Nomenclature, chemical structure, and abbreviations for 16 - priority PAHs $^{(3)}$.

TABLE 5. Concentration of individual PAHs (ng/g dry weight) in the oil extracted from polluted sediments of drainage basin .

\begin{tabular}{|c|c|c|c|c|c|c|}
\hline $\begin{array}{l}\text { Ring I } \\
\text { PAHs }\end{array}$ & & S.NO.7 & S.NO.9 & S.NO.8 & S.NO.10 & S.NO.10* \\
\hline 2Ring & Nap. & N.D. & 7795.9559 & N.D. & 15175.715 & N.D. \\
\hline & Total & N.D. & 7795.9559 & N.D. & 15175.715 & N.D. \\
\hline 3Ring & A. & 4729.2815 & 9766.0046 & 7854.1056 & 10207.524 & 7765.9849 \\
\hline & Ace. & 5473.1024 & N.D. & N.D. & N.D. & N.D. \\
\hline & Phe & 733.353 & 1380.4077 & 999.1343 & 1115.4698 & 1161.6265 \\
\hline & F. & 9628.942 & 8357.5658 & 7234.1061 & 1681.8082 & 10287.232 \\
\hline & Ant. & 984.088 & N.D. & 1753.0902 & N.D. & N.D. \\
\hline & Total & 61548.766 & 19503.977 & 17840.436 & 13004.801 & 19214.843 \\
\hline 4Ring & Flu. & 3041.6255 & 16972.595 & 3924.2012 & 8903.4148 & N.D. \\
\hline & Pyr. & 8441.9379 & 3007.8823 & 10578.204 & 514.771 & 2989.9833 \\
\hline & $\mathrm{BaA}$ & 37.435 & 0.2144 & 11.9342 & 6.7455 & 2.3112 \\
\hline & Chr. & 37.895 & 50.7574 & 64.6989 & 788.1005 & 73.648 \\
\hline & Total & 11558.893 & 20031.448 & 14579.037 & 10213.031 & 3065.9425 \\
\hline 5Ring & $\mathrm{Bbf}$ & 12.3729 & N.D. & 25.6766 & 42.1285 & 22.7754 \\
\hline & $\mathrm{Bkf}$ & 466.695 & 1.1281 & 102.7849 & N. D. & N.D. \\
\hline & BAp & N.D. & N.D. & N.D. & N.D. & N.D. \\
\hline & DahA & N.D. & 32.3083 & N.D. & 700.3045 & N.D. \\
\hline & Total & 479.0679 & 33.4364 & 128.4615 & 742.433 & 22.7754 \\
\hline 6Ring & $\begin{array}{l}\text { Bp } \\
\text { Ip }\end{array}$ & $\begin{array}{l}\text { N.D. } \\
11.1407\end{array}$ & $\begin{array}{l}16.4332 \\
3.717\end{array}$ & $\begin{array}{l}26.8753 \\
9.4161\end{array}$ & $\begin{array}{l}\text { N.D. } \\
44.3801\end{array}$ & $\begin{array}{l}\text { N.D. } \\
30.4232\end{array}$ \\
\hline & Total & 11.1407 & 20.1502 & 36.2914 & 44.3801 & 30.4232 \\
\hline Total F & & 73597.866 & 47384.966 & 32584.225 & 39180.36 & 22333.983 \\
\hline
\end{tabular}

Egypt. J. Chem. 57, No. 3 (2014) 

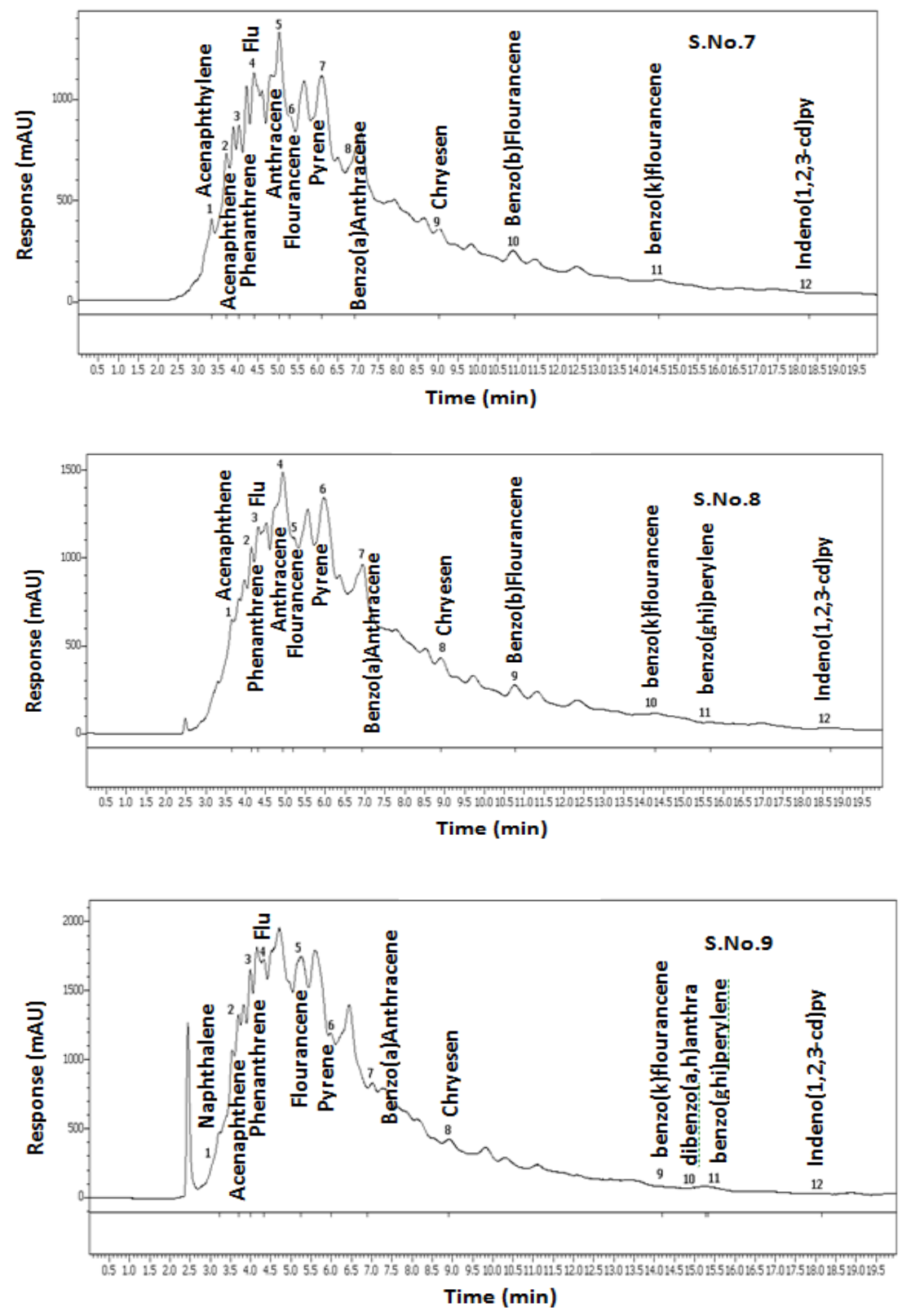

Fig. 5. HPLC chromatograms of extracted oils from discharge basin of SOPC .

Egypt. J. Chem. 57, No. 3 (2014) 
A. M. Mousa et al.
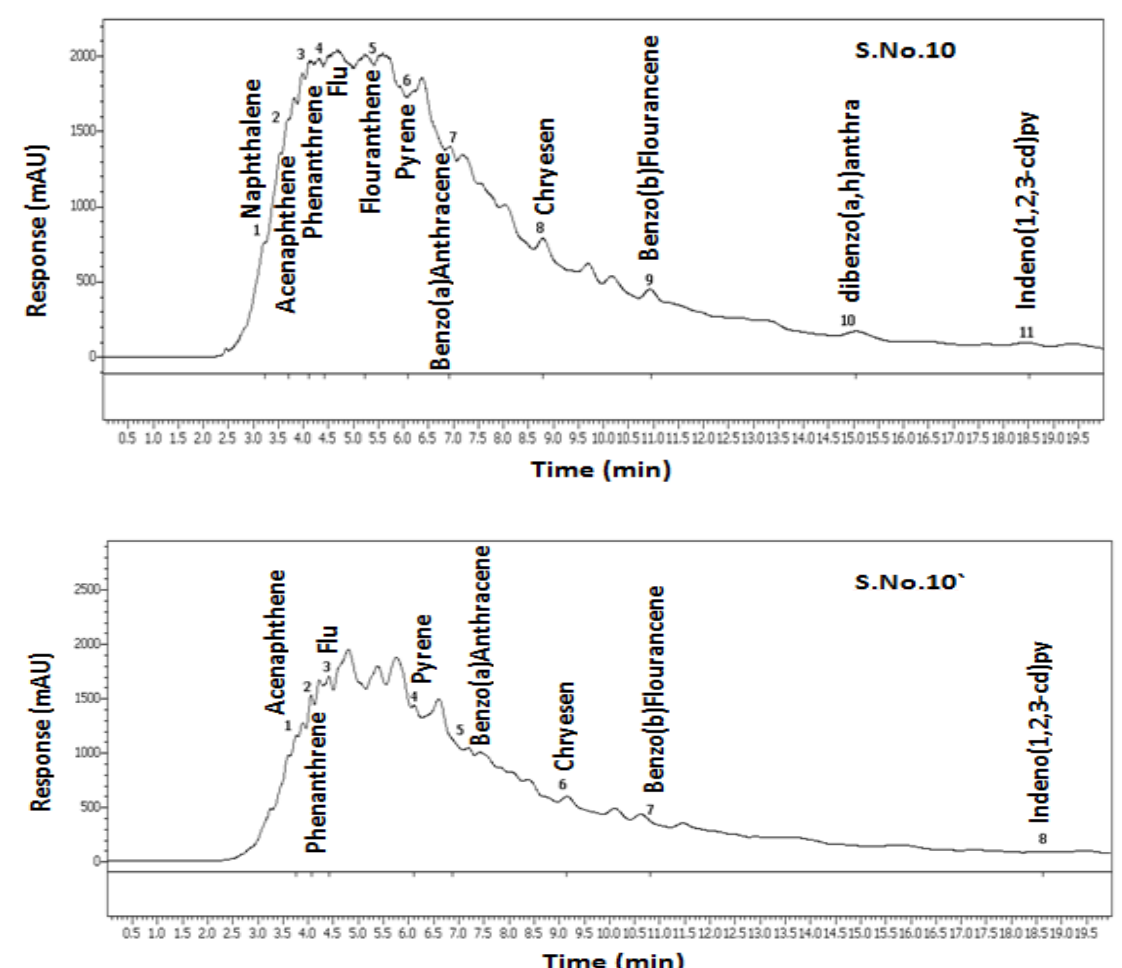

Fig. 6. HPLC chromatograms of extracted oils from discharge basin of SOPC .

TABLE 6. PAHs components (ng/g) and toxicity guidelines .

\begin{tabular}{|l|c|c|c|c|}
\hline Samples station & \multicolumn{5}{c|}{ Guideline } \\
\hline PAHs compounds & ER-L & ER-M & TEL & PEL \\
\hline Naphthalene (Nap) & 160 & 2100 & 34.6 & 391 \\
\hline Acenaphthylene (A) & 44 & 640 & 5.87 & 128 \\
\hline Acenaphthene (Ace) & 16 & 500 & 6.71 & 88.9 \\
\hline Flourene (F) & 19 & 540 & 21.2 & 144 \\
\hline Phenanthrene (Phe) & 240 & 1500 & 86.7 & 544 \\
\hline Anthracene (Ant) & 85.3 & 1100 & 46.9 & 245 \\
\hline Fluoranthne (Flu) & 600 & 5100 & 113 & 1494 \\
\hline Pyrene (Pyr) & 665 & 2600 & 153 & 1398 \\
\hline Benzo [a] anthracene (BaA) & 261 & 1600 & 74.8 & 693 \\
\hline Chrysene ( Chr) & 384 & 2800 & 108 & 846 \\
\hline Benzo [b] fluoranthene (Bbf) & $\mathrm{Na}$ & $\mathrm{Na}$ & $\mathrm{Na}$ & $\mathrm{Na}$ \\
\hline Benzo[K] Fluoranthene (Bkf) & $\mathrm{Na}$ & $\mathrm{Na}$ & $\mathrm{Na}$ & $\mathrm{Na}$ \\
\hline Benzo[a] Pyrene (BAP) & 430 & 1600 & 88.8 & 763 \\
\hline Dibenzo[a,h]anthracene (DahA) & 63.4 & 260 & 6.22 & 135 \\
\hline Indo[1,2,3-cd] perlyene (IP) & $\mathrm{Na}$ & $\mathrm{Na}$ & $\mathrm{Na}$ & $\mathrm{Na}$ \\
\hline Benzo[ghi] perlyene (Bp) & $\mathrm{Na}$ & $\mathrm{Na}$ & $\mathrm{Na}$ & $\mathrm{Na}$ \\
\hline
\end{tabular}

ERL: effect range low, ERM: effect range median, TEL: threshold, Affect level, PEL: probable effect Level. Na: not available.

Egypt. J. Chem. 57, No. 3 (2014) 
TABLE 7. Minimum and maximum concentration (ng/g), of PAHs in the area compared to the guidelines .

\begin{tabular}{|c|l|l|c|c|c|c|}
\hline $\begin{array}{c}\text { Samples } \\
\text { station }\end{array}$ & \multicolumn{7}{|c|}{ Guideline } \\
\hline PAHs Comp. & \multicolumn{1}{|c|}{ Min. } & \multicolumn{1}{|c|}{ Max. } & ER-L & ER-M & TEL & PEL \\
\hline Nap & 7795.959 & 15175.715 & 160 & 2100 & 34.6 & 391 \\
\hline A & 4729.2815 & 10207.524 & 44 & 640 & 5.87 & 128 \\
\hline Ace & N.D. & 5473.1024 & 16 & 500 & 6.71 & 88.9 \\
\hline F & 733.353 & 1380.4077 & 19 & 540 & 21.2 & 144 \\
\hline Phe & 1681.8082 & 10287.232 & 240 & 1500 & 86.7 & 544 \\
\hline Ant & 984.088 & 1753.0902 & 85.3 & 1100 & 46.9 & 245 \\
\hline Flu & 3041.6255 & 16972.595 & 600 & 5100 & 113 & 1494 \\
\hline Pyr & 514.771 & 10578.204 & 665 & 2600 & 153 & 1398 \\
\hline BaA & 0.2144 & 37.435 & 261 & 1600 & 74.8 & 693 \\
\hline Chr & 37.895 & 788.1005 & 384 & 2800 & 108 & 846 \\
\hline Bbf & 12.3729 & 42.1285 & $\mathrm{Na}$ & $\mathrm{Na}$ & $\mathrm{Na}$ & $\mathrm{Na}$ \\
\hline Bkf & 1281 & 466.695 & $\mathrm{Na}$ & $\mathrm{Na}$ & $\mathrm{Na}$ & $\mathrm{Na}$ \\
\hline BAp & N.D. & N.D. & 430 & 1600 & 88.8 & 763 \\
\hline DahA & 32.3083 & 700.3045 & 63.4 & 260 & 6.22 & 135 \\
\hline IP & 3.717 & 44.3801 & $\mathrm{Na}$ & $\mathrm{Na}$ & $\mathrm{Na}$ & $\mathrm{Na}$ \\
\hline Bp & 16.4332 & 28.8753 & $\mathrm{Na}$ & $\mathrm{Na}$ & $\mathrm{Na}$ & $\mathrm{Na}$ \\
\hline
\end{tabular}

ERL: effect range low, ERM: effect range Median, TEL: threshold, Affect level, PEL: probable effect Level, Min.: Minimum, Max.: Maximum, Comp.: Components, N.D. not detected, Na: not available.

PAH compound profiles and origins in polluted sediments of drainage basin

The source analysis results may help us to know about the proportion of pyrogenic and petrogenic origins and it may identify which one is a stronger contributor (Table 8) used to detect the origin of PAHs for the oil extracted from sediment. The sources of PAHs whether from fuel composition (pyrolytic) or from crude oil (petrogenic) contamination, may be identified by ratios of individuals PAH compounds based on peculiarities in PAH composition and distribution pattern as a function of the emission source ${ }^{(38)}$. Ratio values such as phenanthrene /antheracene (Phe /Ant) and fluoranthene /pyrene (Flu/Pyr) had been used by previous workers ${ }^{(39,40)}$. Petroleum often contains more phenanthrene relative to anthracene as phenanthrene that's more a thermodynamically stable tri-cyclic more isomer than anthracene so, Phe/Ant ratio is observed to be very high in PAH petrogenic pollution, but low ratio in pyrolytic contamination cases ${ }^{(41,42)}$. Some authors ${ }^{(38,43)}$ suggest that sediments with Phe/Ant $>10$ were mainly contaminated by petrogenic inputs and Phe/Ant $<10$ was typically of pyrolytic sources. However the ratio of individual PAH compounds varied between sediments, indicating that the sources of PAH contamination might be different. Some sediment samples were under the limit of detection otherwise samples 7 (0.745) and 8 (0.570) (Table 8) suggesting that they were pyrolytic - derived PAHs. The different ratios might also be related to its degree of photo-degradation, chemical degradation or biodegradation and also to the granulometry of the sediment samples. In addition to the Phe/Ant ratio, fluoranthene / pyrene ratio also indicated the origin of PAHs', other author ${ }^{(39)}$ suggested that a Flu/Pyr of less than 1 was attributed to petrogenic sources and values greater than 1 were obviously related to a pyrolytic origin, composition of coal 
and wood gave Flu/Pyr ratio of 1.4 and 1.0 , respectively, while crude oil and fuel oil had values of $0.6-0.9^{(40)}$, samples $7(0.360)$ and $8(0.371)$ had values less than 1 except samples 9,10 had values $5.643 \& 17.296$, respectively. The small Flu/Pyr ratio values suggest strong petrogenic input. In order to provide a good estimation of PAH sources, sediment samples with Phe/Ant $>10$ and Flu/Pyr $<1$ showed strong petrogenic origin, sediment samples with Phe/Ant $<10$ and Flu / Pyr $<1$ were characteristic of mixed pattern of pyrolytic and petrogenic contamination. The benzo [a] anthracene/chrysene $(\mathrm{BaA} / \mathrm{Chr})$ ratio has also been suggested to identify PAH sources, and this ratio in sediment tended to increase as petrogenic contribution decrease $^{(38)}$, the study area reflects values between 0.004 to 0.988 (Table 8) . In addition, (Ant/Ant+Phe) $<0.1$ indicates a petrogenic source, while this ratio indicates a combustion source when it is greater than 0.1 . The ratio of Flu/Pyr $<1$ is characteristic of a petrogenic source and the ratio $\mathrm{Flu} / \mathrm{Pyr}>1$ characterizes a pyrolytic source. Table 8 displays values ranged between 0.360 up to 17.296 indicating multiple sources of Anthropogenic / petrogenic and biogenic PAHs. The ratio (Flu / Flu+ Pyr) differentiates between petroleum, wood, coal and plants combustion. When (Flu / $\mathrm{Flu}+\mathrm{Pyr})<0.5^{(44)}$, it is generally associated with petrogenic source as a characteristic of fuel combustion (gasoline, diesel and crude oil), as samples 7(0.265) and 8(0.271), respectively, while when this ratio exceeds 0.5 as samples $9(0.849)$ and $10(0.945)$, respectively (Table 8), it characterized pyrolytic sources (kerosene, wood, terrestrial plants and coal combustion) ${ }^{(36)}$. Phe/Ant and Ant/Ant+Phe ratios indicate that PAHs present in sediment of discharge basin derived from pyrolytic sources. This pyrolytic origin is however not exclusive since the values of Fluo/Pyr and (Flu / Flu+ Pyr) ratios show the contribution of oil sources (lubricating oils) in sediment of discharge basin indicating mixed origin of PAHs.

Several studies ${ }^{(45-47)}$ reveal that the increased anthropogenic inputs of pyrogenic and petrogenic PAHs in sediments correspond to refinery's effluents and fossil fuel usage in the industrial processes. One of the most used approaches is to compare the sum of several pyrogenic PAHs (4-6-ring PAHs) with a group of petrogenic PAHs (2-3-ring PAHs), since the (2- 3-ring) PAHs are more abundant in petroleum, while highly condensed PAHs (4-6-ring PAHs) are significant combustion products ${ }^{(26)}$.

Pyrogenic sources, such as the combustion-derived particles present in urban atmospheric dust, were depleted in low molecular weight 2-3 ring PAHs (LPAHs) and enriched in high molecular weight 4-6 ring PAHs (HPAHs), which led to an LPAHs/HPAHs ratio $<1$. Petrogenic sources, such as fuel oil or light refined petroleum products, were dominated by low molecular weight PAHs and have LPAHs/HPAHs ratio>1. Indeed the higher the LPAHs/HPAHs ratio is, the higher the prevalence of petrognic sources ${ }^{(39,40)}$. The drainage basin of SOPC recorded values ranged between $1.210-6.160$, Table 8 pointed to multiple sources of anthropogenic / petrogenic and biogenic PAHs, in addition LPAHs/HPAHs ratio $<1$ and Flu/ (Flu+Pyr) ratio $>0.4$ calculated for the five surface sediments suggest pyrogenic sources. These results reveal that the increased anthropogenic inputs of pyrogenic and petrogenic PAHs in sediments correspond to industrial development and fossil fuel usage in the industrial processes beside, continental discharged of the refinery's effluents to the discharge basin.

Egypt. J. Chem. 57, No. 3 (2014) 


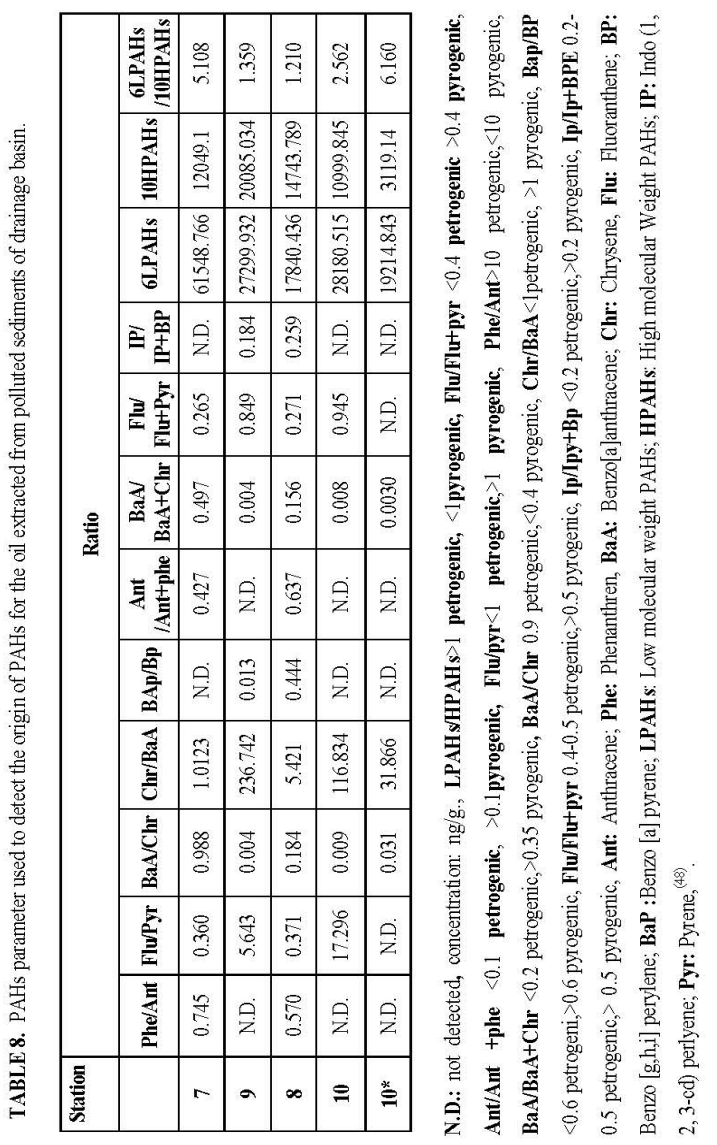

Egypt. J. Chem. 57, No. 3 (2014) 
Distribution of PAHs \% in the oil extracted from polluted sediments of drainage basin

Predominance of low molecular weight PAHs LMW-PAHs (2-3 ring PAHs) and also, high molecular weight PAHs HMW-PAHs (4-ring PAHs) in sediment are in accordance with some other studies, ${ }^{(49,50)}$. 2-3- ring and 4-ring PAHs showed dominance at all the different distances stations of basin. In addition, 5, 6 ring PAHs with low concentrations PAHs compared to the other rings, (Table 5). 2-3 ring PAHs showed dominance at s.no.10*, 7, 10 and 9 with percentage between 54.75 to $86.03 \%$ (Table 9 \& Fig. 7). Beside, four ring PAHs suggests value ranged between 13.73 up to $44.75 \%$ percent represented an increasing percentage for 4-ring distribution at s.no.10, 9, $8 \& 10^{*}$ with values $44.75,42.27,26.07$ and $13.73 \%$, respectively. Penta aromatic ring percentage of higher molecular weight PAHs reverses values between $0.07-1.89 \%$. Indeed, six aromatic ring compounds recorded values ranged between 0.02 to $0.14 \%$ from benzo (ghi) perlyene (Bp) and indeno $(1,2,3 \mathrm{~cd})$ perlyene at all stations. The dominance of the LMW-PAHs due to (2-3 rings) PAHs not subject to any degradation as results of continental discharged of the refinery's effluents to the discharge basin whereas, the HMW-PAHs (4-ring) can be due to their strong adsorbance by sediments. The composition of PAHs in a particular sample usually reflects the sources that produce the PAH. There are three major types of PAH which differ by their genesis: petrogenic, pyrogenic and biogenic. PAHs with 2-3 rings are generally of petrogenic origin, related to petroleum including crude oil and its refined products ${ }^{27,51)}$. High concentrations of phenanthrene indicate the presence of petrogenic sources. The presence of naphthalene at station $9 \& 10$ suggests fresh petroleum pollution ${ }^{(52)}$. PAHs with 4-6 ring hydrocarbons are generally of pyrogenic origin and generated by the combustion of fossil fuels and of recent organic material ${ }^{(27)}$. High concentrations of fluoranthene, pyrene and chrysene found at all stations suggest a pyrogenic origin, as a result of a variety of processing sources and industrial effluents to the discharge basin of SOPC from oily smuggling occuring with water.

TABLE 9. Distribution of PAHs \% in the oil extracted from sediment of drainage basin according to the number of aromatic rings .

\begin{tabular}{|r|l|c|c|c|c|}
\hline S.NO. & \multicolumn{1}{|c|}{ Location } & $\begin{array}{c}\text { 2-3Rings } \\
\mathbf{\%}\end{array}$ & $\begin{array}{c}\text { 4-Ring } \\
\mathbf{\%}\end{array}$ & $\begin{array}{c}\text { 5-Ring } \\
\mathbf{\%}\end{array}$ & $\begin{array}{c}\text { 6-Ring } \\
\mathbf{\%}\end{array}$ \\
\hline $\mathbf{7}$ & $\begin{array}{l}\text { Outlet of Suez Oil Petroleum Company at } \\
\text { 100m. /West. }\end{array}$ & 83.63 & 15.71 & 0.65 & 0.02 \\
\hline $\mathbf{9}$ & $\begin{array}{l}\text { Outlet of Suez Oil Petroleum Company at } \\
50 \mathrm{~m} . / \text { West. }\end{array}$ & 57.61 & 42.27 & 0.07 & 0.04 \\
\hline $\mathbf{8}$ & $\begin{array}{l}\text { Outlet of Suez Oil Petroleum Company at } \\
\text { <50m. /west. }\end{array}$ & 54.75 & 44.75 & 0.39 & 0.11 \\
\hline $\mathbf{1 0}$ & $\begin{array}{l}\text { Outlet of Suez Oil Petroleum Company at } \\
\text { <0m. /east. }\end{array}$ & 71.93 & 26.07 & 1.89 & 0.11 \\
\hline $\mathbf{1 0 *}$ & $\begin{array}{l}\text { Outlet of Suez Oil Petroleum Company at } \\
\text { 100m. /east. }\end{array}$ & 86.03 & 13.73 & 0.10 & 0.14 \\
\hline
\end{tabular}

Egypt. J. Chem. 57, No. 3 (2014) 


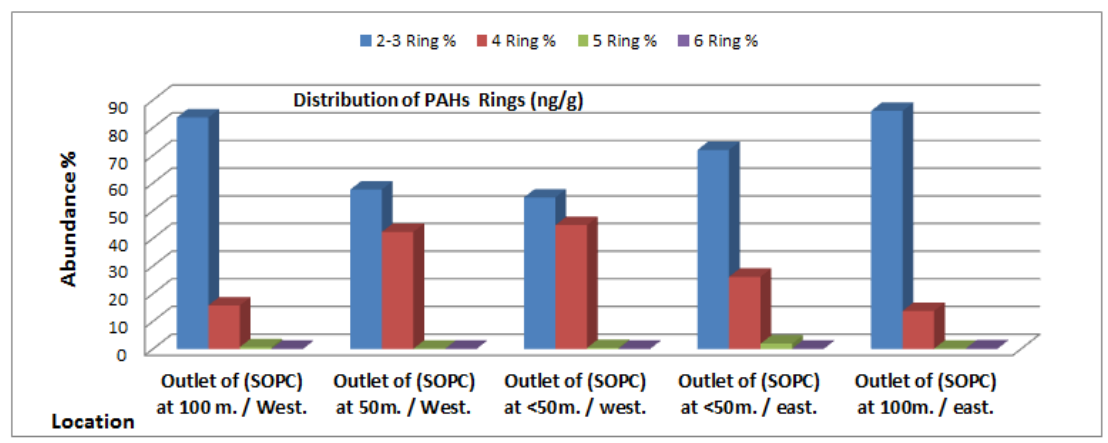

Fig. 7. Histogram representing distribution of PAHs \% in the oil extracted from drainage basin according to the number of aromatic rings .

\section{Conclusion and Recommendations}

The aim of the present study was to investigate and establish the pollution of PAHs in surface sediment along discharge basin of SOPC. HPLC was applied as screening method for the determination of TPAHs in surface sediment. The concentration of PAHs in the sediments ranged between 22333.983 and 73597.864 $\mathrm{ng} / \mathrm{g}$ dry weights with $43016.278 \mathrm{ng} / \mathrm{g}$ dry weights, as the average concentration was greater than the guideline value $(4022 \mathrm{ng} / \mathrm{g})$ and also most PAH components were higher than the ER-L, ER-M, TEL and PEL values moreover, higher by comparison with literature data in various sites in the world, this is due to the deliberate drainage of oily smuggling from the industrial processing which causes continuous inputs and large cumulative loading on the discharge basin water and shore sediments without completely treated (untreated) or degraded easily through weathering processing, consequently, this leads to accumulation of oil residues in sediments. The dominance of the LMW-PAHs due to (2-3 rings) PAHs not subject to any degradation as results of continental discharged of the refinery's effluents to the discharge basin whereas, the HMW-PAHs (4-ring) can be due to their strong adsorbance by sediments. The discharge basin receives PAHs from petrogenic sources, while the major part of PAHs originated from both anthropogenic / petrogenic and biogenic PAH hydrocarbons, due to the elevated levels of PAHs compound in the sediment and also, the high concentration of anthropogenic contaminates including industries, processing activities and other non-point source pollution. The findings point to the urgent need to establish a monitoring programme for persistent organic pollutants not only sediment but also in water to ensure that any excess in concentrations over environmental quality standards is rapidly reported and necessary actions are taken. This study recommended that pollution control for some oily smuggling disposing should be improved by separation of oils water before dumping into the discharge basin, must be committed to the decisions of the IMO declaration and the guideline. The present findings suggest that strict regulations and improvements in the existing environmental legislation should be made to avoid adverse effects to public health both within and outside of the country. 


\section{References}

1. Rooney, P., Factors that influence the petrochemical industry in the Middle East, Middle East Economic Survey, 48, 23 (2005).

2. JAVID, A. and Samadyar, H., Modeling of $\mathrm{pH}$ change impact on heavy metal (nickel and cadmium) transmission in persian gulf (Khour-e Mousa) caused by Bandar Imam Khomeini Petrochemical Complex. Journal of Environmental Science and Technology, (2008).

3. Nazik, A. Farid, Omayma, E. Ahmed and Abd El-Rahman, M. Mousa, Contamination of water, sediment, tar ball and fishes by poly-aromatic hydrocarbons (PAHs) in Alexandria sea coasts. Journal of Applied Sciences Research, ISSN 1819-544X. , 9 (11), 5619-5632 (2013).

4. Deppe, F., Intertidal Mudflats Worldwide, Practical Course at the Common Widen Sea Secretariat (CWSS) in Wilhelmshaven 1st June-30th September (1999).

5. Al-Awadhi, F., The year of the ocean and its crucial importance to the gulf desalination. 123(2-3), 127-133 (1999).

6. Nadim, F., Bagtzoglou, A.C. and Iranmahboob, J., Coastal management in the Persian Gulf region within the framework of the ROPME programme of action. Ocean \& Coastal Management, 51(7), 556- 565 (2008).

7. Price, A., Impact of the Gulf War on the coastal environment and ecosystems: current status and future prospects. Environment International, 24 (1-2), 91-96 (1998).

8. Kennish, M. J., Pollution Impacts on Marine Biotic Communities, CRC Press, Boca Raton, FL, USA, (1997).

9. Guzzella, L., and De Paolis, A., Polycyclic aromatic hydrocarbons in sediments of the Adriatic Sea. Marine Pollution Bulletin, 28, 159 (1994).

10. Fragoso, N.M., Hodson, P.V. and Zambon, S., Evaluation of an exposure assay to measure uptake of sediment PAH by fish. Environmental Monitoring and Assessment, 116(1), 481-511 (2006).

11. Agarwal, T., Khillare, P. and Shridhar, V., PAHs contamination in bank sediment of the Yamuna River, Delhi, India. Environmental Monitoring and Assessment, 123(1),151166 (2006).

12. Massoud, M., Bottom sediments of the Arabian Gulf--II. TPH and TOC contents as indicators of oil pollution and implications for the effect and fate of the Kuwait oil slick. Environmental Pollution, 93(3), 271-284 (1996).

13. RIPI, Contamination of the marine environment from industrial discharges. Research Institute of Petroleum industry (2004).

14. Ghazaleh, M. T., Rosli, H., Abdul Halim, S., Seyedeh, B. T., Sany, Reza, K. J. and Zhamak, M. T., Assessment of contamination by petroleum hydrocarbons in sediments

Egypt. J. Chem. 57, No. 3 (2014) 
of Musa Bay, northwest of the Persian Gulf-Iran, International Conference on Environment, Energy and Biotechnology, vol.33 ( 2012).

15. Dhananjayan, V., Muralidharan, S. and Vinny, R. P., Occurrence and distribution of polycyclic aromatic hydrocarbons in water and sediment collected along the harbors Line, Mumbai, India Hindawi Publishing Corporation, International Journal of Oceanography, Volume Article ID, 403615, p.7,(2012).

16. Remip Working Groups, (WG2), (JICA and EEAA), State of Oil Pollution and Management in Suez Gulf Region, pp. 15, (2008).

17. IP, Standards for Analysis and Testing of Petroleum and Related Products (1993).

18. Shou, F., Richard A. M., Vanessa, A., Casttebery, G., Peter V. W. and Kevin, C. C., High-Performance Liquid Chromatography a., vol.1104, PP. 54-61 ( 2006).

19. Readman, J. W., Fillmann, G., Tolosal, I., Bartocc, J., VillEneuve, J. P., Cattni, C. and Mee, L. D., Petroleum and concentration of The Blank Sea. Marine Bulletin, 44, 48-62 (2002).

20. Viguri, J., Verde, J. and Iranian A., Environmental assessment of polycyclic hydrocarbons (PAHS) surface sediments of the santander by northern Spain. Chemosphere, 48, 157-165 ( 2002).

21. Masoomeh, M., Alireza, S., Yadollah, N. and Kmal, G., Distribution and sources of polycyclic aromatic hydrocarbons, in the sediment of Blusher Coastal Zone-Iran. Iranica Journal of Energy \& Environment, 3 (2), 173-179 (2012).

22. Pozebon, D., Metals, Arsenic and hydrocarbons monitoring in marine sediment during drilling activities using NAFs. Deep-Sea Research II, 56, 22-31 ( 2009).

23. Li, G., Distribution and sources of polycyclic aromatic hydrocarbons in the middle and lower reaches of the Yellow River, China. Environmental Pollution, 144(3), p. $985-993$ (2006).

24. Long, E.R., Incidence of adverse biological effects within ranges of chemical concentrations in marine and estuarine sediments. Environmental Management, International Conference on Ecological Environmental and Bio-Sciences, April 13-15, 2012 Pattaya, 107. 19(1): p. 81-97 (1995).

25. Taatizadeh, H., Evaluation of oil pollution in Bandar-e-Imam Khomeini and offer some recommendation (2009).

26. Ludvik, P., Polycyclic aromatic hydrocarbons in seawater and sediments of the Gulf of Trieste. MSc. Thesis, Nova Garcia, (2010).

27. Liu, Y., Chen, L., Jianfu, Z., Qinghui, H., Zhiliang, Z. and Hongwen, G., Distribution and sources of polycyclic aromatic hydrocarbons in surface sediments of river and estuary in Shanghai, China. Environmental Pollution, 154, 298-305 (2008).

28. Notar, M., Leskov šek, H. and Faganeli, J., Composition, distribution and sources of polycyclic aromatic hydrocarbons in sediments of the Gulf of Trieste, Northern Adriatic Sea. Marine Pollution Bulletin, 42, 36-44 (2001).

Egypt. J. Chem. 57, No. 3 (2014) 
29. Heath, E., Ogrinc, N., Faganeli, J. and Covelli, S., Sedimentary record of polycyclic aromatic hydrocarbons in the Gulf of Trieste (Northern Adriatic Sea). Water, Air and Soil Pollution, Focus 6, 241-250 ( 2006).

30. Zhou, J.L., Hong, H., Zhang, Z., Maskaoui, K. and Chen, W., Multi-phase distribution of organic micro-pollutants in Xiamen Harbor, China. Water Research, 34, 2132-2150 (2000).

31. Baumard, P., Budzinski, H., Garrigues, P., Dizer H. and Hansen, P.D., Polycyclic aromatic hydrocarbons in recent sediments and mussels (Mytilusedulis) from the Western Baltic Sea: occurrence, bioavailability and seasonal variations. Marine Environmental Research, 47, 17-47 (1999).

32. Pereira, W.E., Hostettler, F.D. and Rapp, J.B., Distribution and fate of chlorinated pesticides, biomarkers and polycyclic aromatic hydrocarbons in sediments along a contamination gradient from a point-source in San Francisco Bay, California. Marine Environmental Research, 41, 299-314 ( 1996).

33. Hong, H. L. Xu, Zhang, J.C., Chen, Wong, V.S. and Wan, T.S.M., Environmental fate and chemistry of organic pollutants in the sediments of Xiamen and Victoria harbors. Marine Pollution Bulletin, 31, 229-236 (1995).

34. Chiu-W. C. and Chih F. C., Distribution, origin, and potential toxicological significance of polycyclic Aromatic hydrocarbons (PAHs) in sediments of Kaohsiung Harbor, Taiwan. Marine Pollution Bulletin, 63, 417-423 (2011).

35. USEA Proposed Sediment Quality Criteria for the Protection of Benthic Organisms. EPA882-R-93-012, EPA-882-R-93-013, EPA-882-R-93-014, US. Environ-mental Protection Agency, Office of Water, Washington, DC. (1993).

36. Zrafi, I., Bakhrouf, A., Rouabhia, M. and Saidane, M.D., Aliphatic and aromatic biomarkers for petroleum hydrocarbon, monitoring in Khniss Tunisian-Coast, (Mediterranean Sea). Procedia Environmental Sciences, 18, 211 - 220 (2013)

37. Luch, A., The Carcinogenic Effects of Polycyclic Aromatic Hydrocarbons, Exposure to Common Pollutant in Womb Might Lower I, London: Imperial College Press., ISBN 186094-417-5 (2005).

38. Colombo, J.C., Pelletier, E. and Brochu, M., Determination of hydrocarbon sources using $n$-alkanes and poly-aromatic hydrocarbon distribution indexes. Case study Rio de la Plata Estuary. Argentina. Environmental Science and Technology, 23,888-849 (1989).

39. Sicre, M.A., Marty, J.C., Saliot, A., Aparicio, X., Grimalt, J. and ALbouges, J., Aliphatic and aromatic hydrocarbons different sized a aerosols over the Mediterranean Sea. Occurrence and Origin Atmospheric Environment, 21, 2247-2259 (1987).

40. Soclo, H., Garrigues, P. and Ewald, M., Origin of polycyclic aromatic hydrocarbons (PAHS) in coastal marine sediments: case studies in continuo (Benin and Aquitaine (France) area. Marine Pollution Bulletin, 40, 387-396 (2000).

Egypt. J. Chem. 57, No. 3 (2014) 
41. Gschwend, P. M. and Hites, Ri A., Fluxes of polycyclic aromatic hydrocarbons to marine and Lacutrine sediments in the northeastern United States. Geochemical et Cosmochimica Acta, 45, 3359-2367 (1981).

42. Yang, S.Y., Connell, N., Hawlker, D.W. and Kayal, D.W., Polycyclic aromatic hydrocarbons in air, Soil and vegetation in the vicinity of an urban roadway. The Science of the Total Environmental, 102, 229-240 (1991).

43. Budzinski, H., Jones, I., Beliorg, J., Pierard, C. and Garr Iques, Evaluation of sediment concentration by polycyclic aromatic hydrocarbons in the Gironde Estuary. Marine Chemistry, 58, 85-97 (1997).

44. Tam, N.F.Y., Ke, L. and Wang, Wong, Y.S., Contamination of polycyclic aromatic hydrocarbon in surface sediments of mangrove Swamps. Environmental Pollution, 114, 225-263 (2001).

45. Pereira, W. E., Hostettler, F. D., Luoma, S. N., van Geen, A., Fuller, C. C. and Anima, R. J., Sedimentary record of anthropogenic and biogenic polycyclic aromatic hydrocarbons in San Francisco Bay. California. Marine Chemistry, 64, 99-113 (1999).

46. Arzayus, K.M., Dickhut, R.M. and Canuel, E.A., Effects on the attenuation of polycyclic aromatic hydrocarbons in estuarine sediments. Organic Geochemistry, 33, $1759-1769$ (2002).

47. Frignani, M., Bellucci, L. G., Favotto, M. and Albertazzi, S., Polycyclic aromatic hydrocarbons in sediments of the Venice Lagoon. Hydrobiology, 494, 283 - 290 (2003).

48. Mostafa M. Emara, Nazik A. Farid, Enas A. El-Sabagh, Omayma E. Ahmed and Eman M. Kamal, Origin and distribution of polycyclic aromatic hydrocarbons (PAHs) In surface water of Suez Gulf. Egypt. J. Anal. Chem. 23, 54-73 (2014).

49. Qiu, Y.W., Zhang, G., Liu, G.Q., Guo, L.L., Li, X.D. and Wai, O., Polycyclic aromatic hydrocarbons (PAHs) in the water column and sediment core of Deep Bay, South China. Estuarine, Coastal and Shelf Science, 83, 60-66 (2009).

50. Zhou, J. L. and Maskaoui, K., Distribution of polycyclic aromatic hydrocarbons in water and surface sediments from Day Bay, China. Environmental Pollution, 121, 269281(2003).

51. Valavanidis A., Vlachogianni, Th., Triantafillaki, S., Dassenakis, M., Androutsos, F. and Scoullos, M., Polycyclic aromatic hydrocarbons in surface seawater and in digenous mussels (Mytilusgalloprovincialis) from coastal areas of the Saronikos. in Gulf, Greece. Estuarine, Coastal and Shelf Science, 79, 733-739 (2008).

52. Robertson, A., Petroleum hydrocarbons In: AMAP Assessment Report, Arctic Pollution Issues, 661-716 (1998).

Received 17/8/2014 ;

accepted 16/9/2014) 


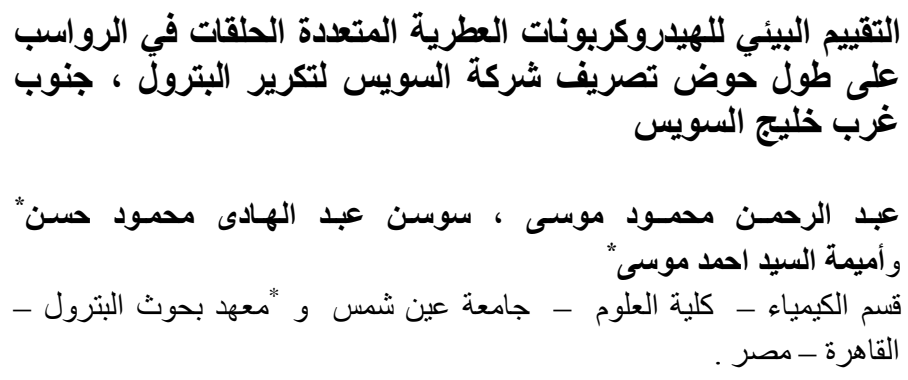

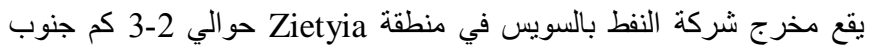

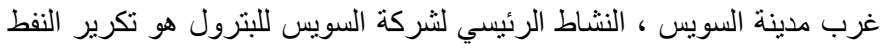

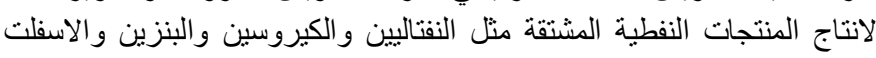

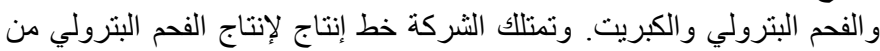

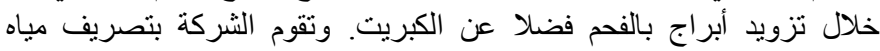

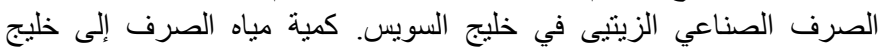

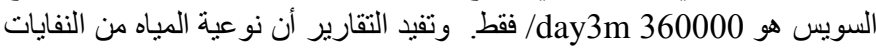

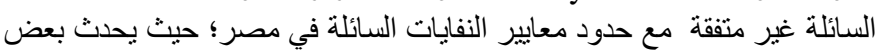

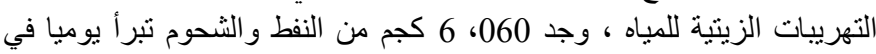

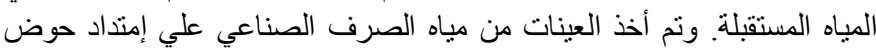

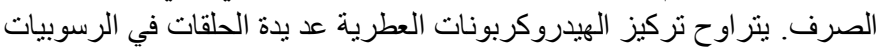

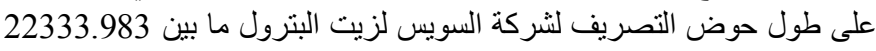

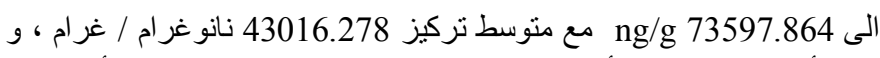

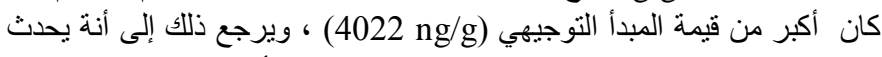

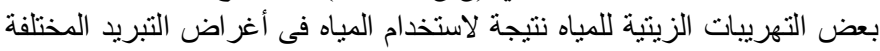

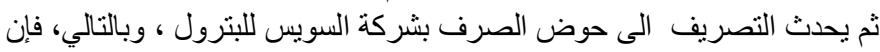

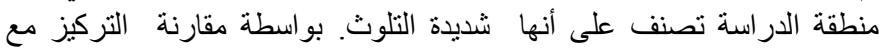

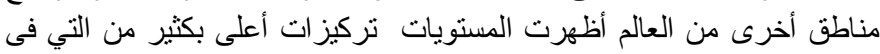

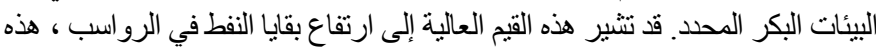

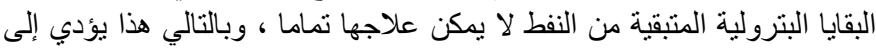

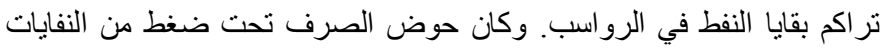

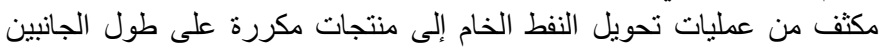

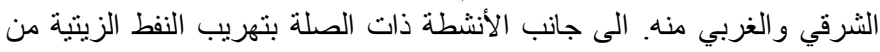

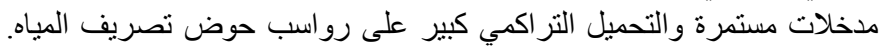

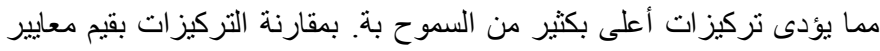

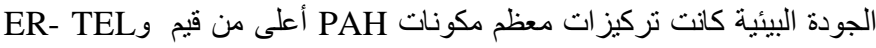

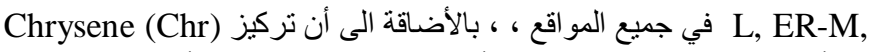

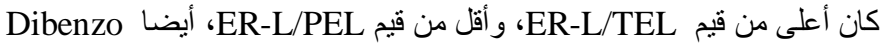

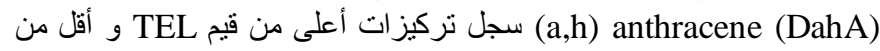

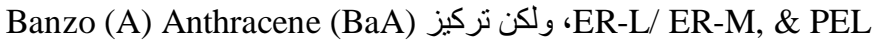
أقل من قيم ER-L/ ER-M,و TEL /PEL في جميع المواقع، وجود الحلقات

Egypt. J. Chem. 57, No. 3 (2014) 
على طول حوض تصريف الثركة في الرواسب جنبا إلى جنب مع المركبات

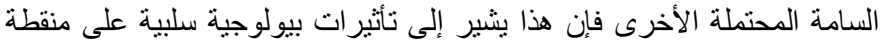

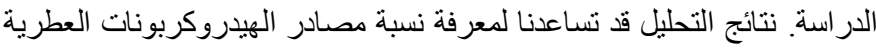

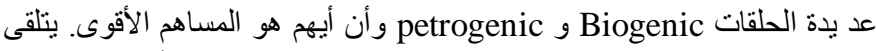

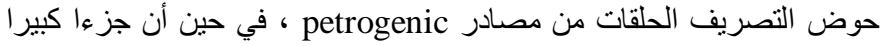

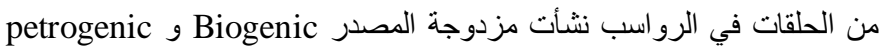

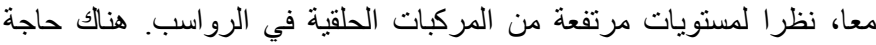

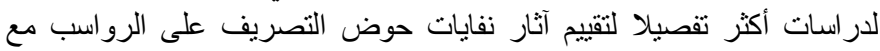

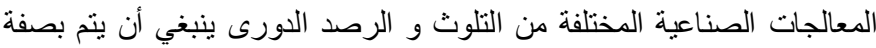

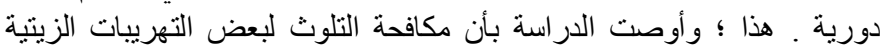

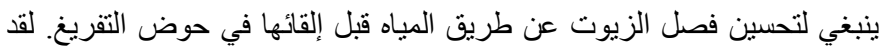

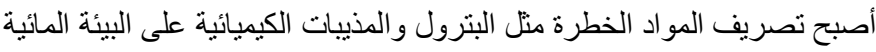

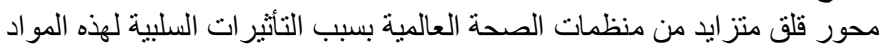

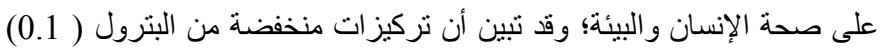

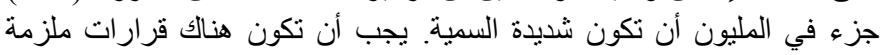

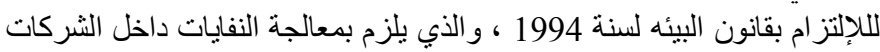

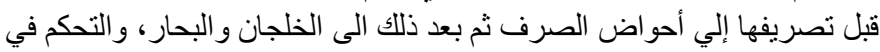

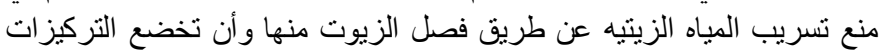
للمعايير المسموح بها عالميا. 